\title{
First report of the parasitic copepod Lernaea cyprinacea (Copepoda: Lernaeidae) on gobioid fishes (Teleostei: Gobonellidae) in southern Europe
}

\author{
Harald Ahnelt ${ }^{1,2,}{ }^{*}$, Robert Konecny ${ }^{3}$, Andreas Gabriel ${ }^{1}$, Andreas Bauer ${ }^{1}$, Laura Pompei ${ }^{4}$, \\ Massimo Lorenzoni ${ }^{4}$ and Helmut Sattmann ${ }^{5}$ \\ ${ }^{1}$ Department of Theoretical Biology, University of Vienna, Althanstrasse 14, 1090 Vienna, Austria \\ ${ }^{2}$ First Zoological Department, Natural History Museum in Vienna, Burgring 7, 1010 Vienna, Austria \\ ${ }^{3}$ Environment Agency Austria, Spittelauer Lände 5, 1090 Vienna, Austria \\ ${ }^{4}$ Department of Chemistry, Biology and Biotechnologies, University of Perugia, via Elce di Sotto, 06123 Perugia, Italy \\ 5 Third Zoological Department, Natural History Museum in Vienna, Burgring 7, 1010 Vienna, Austria
}

\begin{abstract}
Lernaea cyprinacea is a non host-specific parasitic copepod known to infest many freshwater fish species. Outbreaks of infestations by this ectoparasite may cause mass mortality of parasitized fishes. L. cyprinacea has been found mostly on pelagic species. Records on small benthic fish species are less common. Especially rare are infestations of Gobioidei adapted to a benthic life style, with reports restricted to Asia and, in Europe, to the Ponto-Caspian region. Although it is cosmopolitan, L. cyprinacea has rarely been found in Italy. One of the few Italian localities with documented infestations is Lake Trasimeno, a lake with an economically important fishery. Although endoparasites of commercially interesting fish species in this lake are well documented, information about ectoparasites is rare. In May 2015, specimens of two gobioids Knipowitschia panizzae and Pomatoschistus canestrinii - infested with L. cyprinacea were sampled at the south shore of Lake Trasimeno. Both gobies are not native to the lake. This is the first documentation of gobioid fishes as hosts of L. cyprinacea in Italy and in Europe (outside of the Ponto-Caspian region). Although both gobies are not optimal hosts (small size, short life expectancy) they have the potential to carry and to transmit the parasite in freshwater habitats, e.g. by unintentional introduction with fry of other fish species.
\end{abstract}

Keywords: Lernaea / Copepoda / Knipowitschia / Pomatoschistus / Italy / River Tiber basin / Lake Trasimeno

\begin{abstract}
Résumé - Premier signalement du copépode parasite Lernaea cyprinacea (Copepoda: Lernaeidae) sur des poissons gobioides (Téléostéen: Gobioidei) dans le sud de l'Europe. Lernaea cyprinacea est un copépode parasite non spécifique de l'hôte, connu pour infester de nombreuses espèces de poissons d'eau douce. Les foyers d'infestation par cet ectoparasite peuvent causer une mortalité massive de poissons parasités. L. cyprinacea a été trouvée principalement sur des espèces pélagiques. Les données sur les petites espèces de poissons benthiques sont moins courantes. Les infestations de Gobioidei adaptés à un mode de vie benthique sont particulièrement rares, avec des signalements limités à l'Asie et, en Europe, à la région de Ponto-Caspienne. Bien que cosmopolite, L. cyprinacea a rarement été trouvée en Italie. L'une des rares localités italiennes avec des infestations documentées est le lac Trasimène, un lac avec une pêche économiquement importante. Bien que les endoparasites d'espèces de poissons commercialement intéressantes dans ce lac soient bien documentés, l'information sur les ectoparasites est rare. En mai 2015, des spécimens de deux gobioidés - Knipowitschia panizzae et Pomatoschistus canestrinii - infestés par L. cyprinacea ont été échantillonnés sur la rive sud du lac Trasimène. Les deux gobies ne sont pas indigènes au lac. Il s'agit de la première documentation de poissons gobioides comme hôtes de L. cyprinacea en Italie et en Europe (en dehors de la région Ponto-Caspienne). Bien que les deux gobies ne soient pas des hôtes optimaux (petite taille, espérance de vie courte), ils ont le potentiel de transporter et de transmettre le parasite dans les habitats d'eau douce, par exemple par introduction involontaire avec des alevins d'autres espèces de poissons.
\end{abstract}

\footnotetext{
*Corresponding author: harald.ahnelt@univie.ac.at
} 


\section{Introduction}

Lernaeidae are cyclopoid freshwater copepods. The females are morphologically highly modified and adapted to a parasitic life style. The only cosmopolitan species is Lernaea cyprinacea Linnaeus, 1758, the "anchor worm". It is of Eurasian origin and was unintentionally introduced worldwide with parasitized cyprinid fish stocks (Tidd, 1934; Marina et al., 2008; Avenant-Oldewage, 2012; Walter and Boxshall, 2018). After the females have burrowed into the skin of the host, their cephalothorax develops lateral processes as holdfasts, the name-giving "anchor". Outbreaks can cause mass mortality of parasitized fishes and severe commercial losses (e.g. Piasecki et al., 2004; Boxshall and Defaye, 2008; Fast, 2014), but in natural fish populations of temperate regions this parasite is apparently not common (e.g. Cloutman, 1903; Piasecki et al., 2004; Bednarska et al., 2009). Nevertheless, global warming by climate change may favor the increasing occurrence of the thermophilic L. cyprinacea.

This parasite is adapted to freshwater hosts, generally fishes (Kabata, 1979; Piasecki et al., 2004), but it also infests amphibians (Kupferberg et al., 2009, Salinas et al., 2016) and aquatic insects (McAllister et al., 2011). Most infested fish species have a pelagic life style. Benthic species are less often infested (Djikanovic et al., 2012; Koyun et al., 2015). Especially Gobioidei, a clade of fishes adapted primarily to a benthic life style, are rarely infected by L. cyprinacea (e.g. Kvach, 2004; Nagasawa et al., 2007; Kvach et al., 2015; Zhokhov et al., 2017). All records to date of infested Gobioidei were from Asia and from the Ponto-Caspian region (Tab. S1).

Reports of L. cyprinacea in Italy in general (Fratello and Sabatini, 1972; Macchioni et al., 2015) and from Lake Trasimeno in particular (Fratello and Sabatini, 1972) are scarce. A single record of L. cyprinacea from the pelagic fish species Lepomis gibbosus (Linnaeus, 1758) dates back to the early 1970s. In the following years no further records were documented. Most fish species of the lake are well studied, including their parasites (Lorenzoni et al., 2002, 2010, 2015; Giovinazzo et al., 2006; Pompei et al., 2012). The finding of L. cyprinacea in Lake Trasimeno and in particular on the small benthic gobionellid fishes Knipowitschia panizzae (Verga, 1841) and Pomatoschistus canestrinii (Ninni, 1883) is therefore remarkable.

The present study reports (1) the first documentation of an infection with L. cyprinacea of two gobionellid species endemic to the Adriatic basin, (2) the first infestation with this parasite of gobioid species in Europe outside the PontoCaspian region and finally (3) an extension of host species for L. cyprinacea.

\section{Materials and methods}

\subsection{Study locality}

Fisheries are a highly important economic sector in Lake Trasimeno $\left(43^{\circ} 06^{\prime} \mathrm{N}, 12^{\circ} 07^{\prime} \mathrm{E}\right)$, which boasts the largest group of professional fishers in inland Italian lakes and is an aquaculture center for fish breeding. It is the fourth largest lake in Italy $\left(124 \mathrm{~km}^{2}\right)$ and meso-eutrophic with low water transparency (average Secchi disk depth $=1 \mathrm{~m}$ ) (Giardino et al., 2010). Because the lake is shallow (average depth: $4.7 \mathrm{~m}$ ), thermal stratification is usually absent and the water temperature is always about the same as the air temperature: it can exceed $30^{\circ} \mathrm{C}$ during summer (Lorenzoni et al., 2010; Ludovisi and Gaino, 2010). The fish assemblage comprises 19 species, most of which are alien species and is dominated by cyprinids including tench (Tinca tinca (Linnaeus, 1758)), carp (Cyprinus carpio Linnaeus, 1758), goldfish (Carassius sp.) and rudd (Scardinius hesperidicus Bonaparte, 1845). Other common species are southern pike (Esox cisalpinus Bianco and Delmastro, 2011), perch (Perca fluviatilis Linnaeus, 1758), largemouth bass (Micropterus salmoides (Lacepéde, 1802)) and sandsmelt (Atherina boyeri Risso, 1810) (Lorenzoni et al., 2010).

Sampling was conducted in May 2015 at the southeast shore of the lake near the large aquaculture center, where submerged vegetation dominates the bottom (Giovanardi et al., 2010).

Comparative material was investigated from two natural populations: $K$. panizzae from the brackish waters of the abandoned salt-works of Zaule $\left(45^{\circ} 36^{\prime} \mathrm{N}, 13^{\circ} 46^{\prime} \mathrm{E}\right)$ directly south of Trieste and P. canestrinii from the lower reaches of the karst river Jadro at Solin $\left(43^{\circ} 32^{\prime} \mathrm{N}, 16^{\circ} 29^{\prime} \mathrm{E}\right)$ near Split. These samples were collected at the end of the 19th century, are deposited at the Ichthyological collection of the First Zoological Department (Vertebrata) of the Natural History in Vienna (NMW), and registered by the numbers NMW 29806-807, NMW 29809 (K. panizzae) and NMW 30371-373 (P. canestrinii).

\subsection{Material}

We investigated a total of 427 specimens of $K$. panizzae and P. canestrinii: 391 gobies from Lake Trasimeno (Italy), 86 from Zaule near Trieste (Italy) and 50 from the Jadro River near Split (Croatia). Samples from Lake Trasimeno were captured in May $(n=182)$ and November $2015(n=209)$.

From the specimens collected in Lake Trasimeno during the reproductive period in May 2015, 42 specimens were adult K. panizzae (mean $22.4 \mathrm{~mm} \mathrm{SL}$ ) (23 males and 19 females) and 140 specimens were adult $P$. canestrinii (mean $27.3 \mathrm{~mm} \mathrm{SL}$ ) (79 males and 61 females). Sex and maturity were determined based on the shape of the urogenital papilla (longer than wide in males, shorter and about as long as wide in females) and by inspecting the gonads.

Fish samples were caught under the permission of the state and regional institutions and were in accordance with Italian state laws on fisheries.

\subsection{Methods}

The fishes were captured using landing nets with a mesh width of $5 \mathrm{~mm}$. They were anesthetized and subsequently euthanized by an overdose of 2-phenoxyethanol and stored in $6 \%$ formalin for several weeks. After passing through an ascending series of ethanol, the specimens were stored in $70 \%$ ethanol.

Fish were examined for the presence of parasites under a stereo microscope. Crustacean parasites found were carefully removed from the fish, transferred to a 1:1 mixture of 
glycerine-ethanol (glycerol 99.5\% AnalaR Normapur; ethanol $80 \%$ ). The samples were kept in an incubator (Memmert, Germany) for $24 \mathrm{~h}$ at $40^{\circ} \mathrm{C}$ to evaporate ethanol and condense glycerol. Objects were then placed on microscopic glass slides and mounted in pure glycerine under a cover glass. Micrographs and measurements were taken under a Nikon Eclipse Ni transmitted light microscope with a Nikon DS Ri2 camera.

Collected specimens of L. cyprinacea are deposited in the Collection Crustacea of the Natural History Museum in Vienna with the register number NHMW 26.266.

Information on infestation of gobioid species with L. cyprinacea and of gobioid species not infested but cooccurring with infested species listed in Table S1 was retrieved from the literature.

Parasitological prevalence (percentage of hosts infected with parasites) is based on Bush et al. (1997).

\section{Results}

We found $4.8 \%$ of $K$. panizzae $(n=2)$ and $5 \%$ of P. canestrinii $(n=7)$, collected in Lake Trasimeno in May 2015 to be infested by L. cyprinacea .

Two females of $K$. panizzae were infested. The parasites were attached (i) at the right side of the anal fin base close to the origin of the fin $(n=1)$; (ii) between the urogenital papilla and the origin of the anal fin (Fig. 1). Five male and two female $P$. canestrinii were infested. The parasites were attached to the males at the (i) ventral side of the head $(n=2)$; (ii) ventral side of the abdomen at the origin of the pelvic fins (sucking disc) $(n=1)$ (Fig. 1); (iii) internal origin of the pectoral fin $(n=1)$ and (iv) in the opercular chamber $(n=2)$. The parasites were attached to the females at the internal origin of the pectoral fin $(n=2)$. No host was infested by more than one parasite.

Measurements of the four L. cyprinacea specimens are provided in Table 1.

None of the specimens sampled in Lake Trasimeno in November 2015 and none from the natural habitats (K. panizzae from Zaule near Trieste and P. canestrinii from Jadro River near Split) were infested.

The literature survey revealed that nine gobioid species from Asia and from the Ponto-Caspian region were reported as being infested by L. cyprinacea. At the same time, five gobioid species sympatrically occurring with parasitized fish species were not infested (Tab. S1). Nearly all these documentations of infestations of Gobioidei were based on single records only and not recorded a second time.

\section{Discussion}

K. panizzae and $P$. canestrinii are euryhaline (5-20\%o) and short-lived (about one year) gobies endemic to the Adriatic region (summarized in Miller, 2004). The two species were introduced unintentionally into Lake Trasimeno, where they established large reproducing populations (Borroni, 1976; Freyhof, 1998). We found a low prevalence $(\sim 5 \%)$ of the ectoparasite L. cyprinacea for both goby populations. There are no records on infestation of these two gobionellid species in their natural distribution area. This is probably because both prefer habitats of low salinity, an environment not suitable for the strictly freshwater parasite L. cyprinacea.

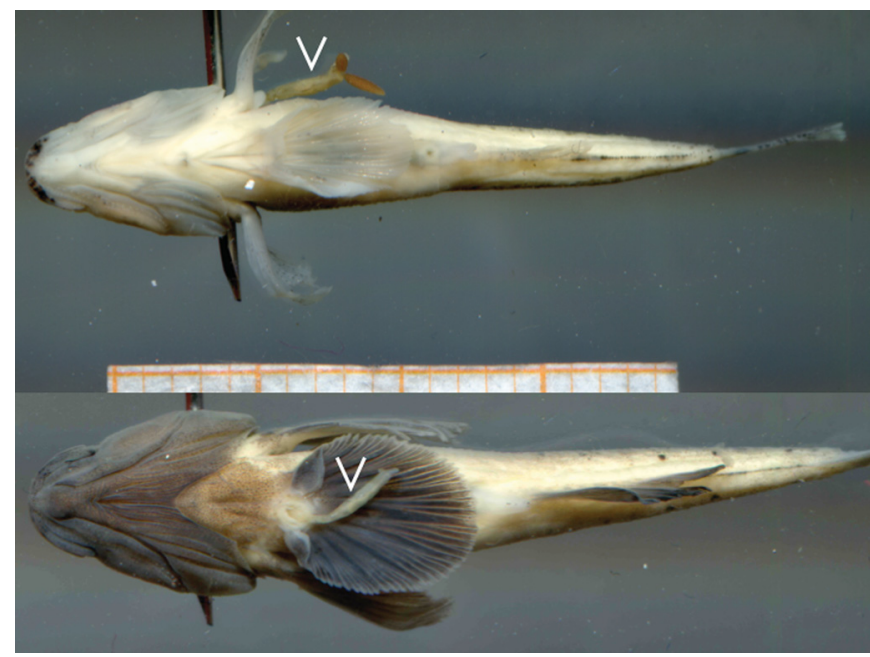

Fig. 1. Lernaea cyprinacea (white arrow heads) attached to host Pomatoschistus canestrinii; above female, below male. Female: parasite is attached medially on left pectoral fin base. Male: parasite is attached on origin of pelvic fins (united to a sucking disc). Hosts are shown in ventral view. Scale $=20 \mathrm{~mm}$. Photos: A. Gabriel.

A first record of an unidentified Lernaeidae (as Lernaea sp.) for Lake Trasimeno was reported in the 1960s from the South European roach Sarmarutilus rubilio (Bonaparte, 1837) (as Rutlius rubilio) as a host (Cianficconi, 1966). The first and only confirmed occurrence of $L$. cyprinacea in this lake dates back to the early 1970s, when this ectoparasite was detected on the introduced pumpkinseed L. gibbosus (Fratello and Sabatini, 1972). Unidentified Lernaeidae were found recently on introduced largemouth bass (M. salmoides) (Dr. M. Natali, pers. communication). From these few records we conclude that outbreaks of laerneosis are rather uncommon in Lake Trasimeno. This corresponds to our finding of an apparently low (5\%) infestation rate of the two gobionellid lake populations.

Apart from unclear synonymies, the present material was assigned to L. cyprinacea. It can be easily distinguished from L. parasiluri Yamaguti, 1939 by its second pair of head processes, from L. esocina (Burmeister, 1833) by its distinctly unequal anterior and posterior head processes (anchor) (comp. Bykhovskaya-Pavlovskaya et al., 1964).

The body dimensions of females are highly variable in L. cyprinacea. This has led to different suggestions about (sub) species or geographic delimitation by some authors (comp. Demaree, 1967; Nagasawa et al., 2007; Stavrescu-Bedivan et al., 2014). The dimensions measured in our sample are within the range given for North America (Tidd, 1933; Demaree, 1967), i.e. 1.4-11.7 mm total length, and also similar to Japanese forms (5.8-8.0 mm; comp. Demaree, 1967). Both are assumed to be smaller than those from Europe and Asia, which Bykhovskaya-Pavlovskaya et al. (1964) reports as 9-22 mm, and other authors (for Europe) as 9-11.7 mm (comp. Demaree, 1967). In the future we hope to study a higher number of these parasites from both fish species based on newly collected material and also to obtain material suitable for molecular studies to compare it with sequences from other findings.

Sympatrically occurring fish species often show divergent infestation rates by L. cyprinacea. This was linked to several 
H. Ahnelt et al:: Knowl. Manag. Aquat. Ecosyst. 2018, 419, 34

Table 1. Measurements of four individuals of Lernaea cyprinacea of the host Pomatoschistus canestrinii from Lake Trasimeno, Italy; in mm.

\begin{tabular}{lllll}
\hline & Ind. A & Ind. B & Ind. C & Ind. D \\
\hline Lateral extent anchor & 1.55 & 1.82 & 2.39 & 1.93 \\
Length cephalothorax + trunk & 3.65 & 5.64 & 4.92 & 6.49 \\
Length abdomen & 0.57 & 0.63 & 1.09 & 0.52 \\
Total body length & 4.22 & 6.27 & 6.01 & 7.01 \\
Width posterior end of trunk & 0.85 & 0.91 & 1.39 & 0.99 \\
Length egg sac & 1.55 & - & - & - \\
Length egg sac & 1.43 & - & - & 0.31 \\
Length progentital prominence & - & - & & 1.95 \\
\hline
\end{tabular}

extrinsic and intrinsic factors such as resistance against infection (Shariff and Roberts, 1989; Stavrescu-Bedivan et al., 2014), different trophic behavior (Alam et al., 2012; Iqbal et al., 2012), temperature fluctuations (Raissy et al., 2013; StavrescuBedivan et al., 2014), hydrodynamic conditions (Medeiros and Maltchik, 1999), microhabitat differences (Kadlec et al., 2003; Stavrescu-Bedivan et al., 2014; Innal et al., 2017) or small size (Piasecki et al., 2004; Stavrescu-Bedivan et al., 2011; Innal et al., 2017). Our literature survey revealed that predominantly pelagic fish species were targets of $L$. cyprinacae, less often small benthic species such as Cobitidae, Cottidae or Gobiidae (e. g. Pónyi and Molnár, 1969; Amin, 1981; Djikanovic et al., 2012; Koyun et al., 2015). This possibly reflects a combination of different size and microhabitat segregation of sympatrically occurring fish species. This is supported by Raibaut et al. (1998), who attributed a low copepod-host ratio to a combination of a benthic life style and small size of fishes, specifically also referring to Gobiidae. This combination of life style and size probably explains why freshwater gobies are rarely infected by L. cyprinacea (e.g. Kvach, 2002; Nagasawa et al., 2007; Zhokhov et al., 2017) (Tab. S1). This ectoparasite, however, has been found on many freshwater species of several fish families (Amin, 1981; Koyun et al., 2015, Sánchez-Hernández, 2017; Waicheim et al., 2017) but only rarely on gobioid species (Tab. S1). Although occurring sympatrically with infected fishes, gobioid fishes were often not infested by L. cyprinacea (e.g. Kritscher, 1975; Kvach, 2004; Dalu et al., 2012; Krasnovyd et al., 2012; Kvach et al., 2014, 2015; Zhokhov et al., 2017) (Tab. S1).

Larger fishes often carry many parasites (e.g. Whitaker and Schlueter, 1975). We attribute the low host-parasite ratio in Lake Trasimeno in general, and the infestation of the gobies by only a single parasite in particular, primarily to the small size of the fish $(<5 \mathrm{~cm})$ and less to their benthic life style. All infested gobies of Lake Trasimeno were adults. An infestation by more than one parasite may well be lethal for these small fishes because the tissue penetration by the parasite causes severe damage (Piasecki et al., 2004; Boxshall and Defaye, 2008; Avenant-Oldewage, 2012; Stavrescu-Bedivan et al., 2014). Moreover, the life span of both species is too short (about one year) to allow these female parasites to hibernate on their hosts as they do on perennial species (Hossain et al., 2013). We therefore we assume that $K$. panizzae and $P$. canestrinii are not optimal hosts for L. cyprinacea.

Because juvenile L. cyprinacea are unable to complete their development at temperatures below $20^{\circ} \mathrm{C}$, outbreaks generally occur at higher temperatures (Kupferberg et al.,
2009; Hossain et al., 2013). Most favorable for the development of the parasite are temperatures ranging from 25 to $28^{\circ} \mathrm{C}$ (Piasecki et al., 2004), $24-29^{\circ} \mathrm{C}$ after Shields and Tidd (1968) and $26-30^{\circ} \mathrm{C}$ after Hossain et al. (2013). Similar high water temperatures are reached in Lake Trasimeno from May to September but may extend into October (Ludovisi and Gaino, 2010; ARPA Umbria, 2018). The annual average water temperature in the lake has increased since the late 1980 s by $1{ }^{\circ} \mathrm{C}$ in summer and by $1.3{ }^{\circ} \mathrm{C}$ in spring (March-May) $\left(0.65^{\circ} \mathrm{C}\right.$ per decade from 1988 to 2006) (Ludovisi and Gaino, 2010). Annual average air temperature in the Lake Trasimeno basin is predicted to rise between $2{ }^{\circ} \mathrm{C}$ (min.) and $4.5^{\circ} \mathrm{C}$ (max.) until 2090 (Ludovisi et al., 2013), which is in agreement with temperature changes predicted for southern Europe (Intergovernmental Panel on Climate Change (IPCC), 2007). Therefore, infestation periods may last distinctly longer in shallow lakes such as Lake Trasimeno, where water temperature is nearly identical to the air temperature (Lorenzoni et al., 1993; Ludovisi and Gaino, 2010). Hostparasite interactions are affected both by temperature and other climate-driven variables such as changing water level, reduced precipitation, eutrophication or habitat loss (Marcogliese, 2001, 2008, Marcogliese et al., 2016). All these effects are currently already distinctly altering the environment around Lake Trasimeno (Ludovisi and Gaino, 2010; Ludovisi et al., 2013). Nevertheless, temperature is the master factor for ectotherms in aquatic environments (Webb and Nobilis, 2007; Narum et al., 2013). This makes it likely that, due to rising temperatures, more generations and larger populations of parasites will influence host-parasite interactions in Lake Trasimeno; higher temperatures are believed to favor higher infestation levels of L. cyprinacea (Kupferberg et al., 2009).

\section{Conclusions}

Two single records of L. cyprinacea in Lake Trasimeno date back to the late 1960s and early 1970s, respectively, and because the host-parasite ratio documented in this study is also low, we assume that the parasite is still rare in the lake. The period of successful development of $L$. cyprinacea in this lake is limited to May-October. As a result of climate change, a combination of climate-driven effects such as temperature, changing water level, eutrophication or habitat loss will likely influence host-parasite interactions in Lake Trasimeno. Increasing temperatures will extend the reproductive period and, consequently, infestation rates of this parasite could 
increase. Although $K$. panizzae and $P$. canestrinii are not optimal hosts for this parasite based on their small size and short life span, they are carriers, potential transmitters and a potential refuge for the copepod ectoparasite L. cyprinacea because of their cryptic life-style.

\section{Author's contributions}

HA conceived the study, provided ichthyological advice and wrote the manuscript. RK and HS morphologically identified the parasite specimens and contributed to writing the manuscript. $\mathrm{AG}$ and $\mathrm{AB}$ identified the fish specimens, contributed to the data sampling and prepared photographs. LP and ML collected the specimens and contributed to writing the manuscript. All authors read and approved the final version of the manuscript.

\section{Supplementary Material}

Supplemenatary data.

The Supplementary Material is available at https://www. kmae-journal.org/10.1051/kmae/2018022/olm.

Acknowledgements. We are grateful to Mauro Natali for information on lernaeid infestation of fishes in Lake Trasimeno and to D. J. Marcogliese for providing literature.

\section{References}

Alam MM, Khan MA, Hussain MA, Moumita D, Mazlan AG, Simon KD. 2012. Intensity of parasitic infection in silver carp, Hypophthalmichthys molitrix. J Zhejiang Univ-Sci B, Biomed Biotechnol 13: 1024-1028.

Amin OM. 1981. On the crustacean ectoparasites of fishes from Southeast Wisconsin. Trans Am Microsc Soc 100: 142-150.

ARPA Umbria. 2018. Dataset retrieved from http://www.arpa.umbria. it/pagine/balneazione-lago-di-piediluco on January 2018.

Avenant-Oldewage A. Lernaea cyprinacea and related species. In: Woo PTK, Buchmann K, eds. Fish parasites: pathobiology and protection. London (UK): CAB International, 2012, pp. 337-359.

Bednarska M, Bednarski M, Soltysiak Z, Polechoński R. 2009. Invasion of Lernaea cyprinacea in rainbow trout (Oncorhynchis mykiss). Acta Sci Polon, Medic Vet 8: 27-32.

Borroni I. 1976. Involontaria introduzione nel Lago Trasimeno (Umbria) di un gobide diacqua salmastra (Knipowitschia panizzae) e seguito di pratiche ittiogeniche. Mem Ital Idrobiol 33: 297-304.

Boxshall GA, Defaye D. 2008. Global diversity of copepod (Crustacea: Copepoda) in freshwater. Hydrobiologia 595: 195-207.

Bush AO, Lafferty KD, Lotz JM, Shostak AW. 1997. Parasitology meets ecology on its own terms: Margolis et al. Revisited. J Parasitol 83: 575-583.

Bykhovskaya-Pavlovskaya IE, Gusev AV, Dubinina MN, Izyumova NA, Smirnova TS, Sokolovskaya IL, Shtein GA, Shulmann SS, Epshtein VM. 1964. Key to parasites of freshwater fish of the U.S.S. R. Jerusalem: Israel Program for Scientific Translations 1136, 887 p.

Cianficconi F. 1966. Sulle possibilità di allevamento artificiale della lasca del Trasimeno (Rutilus rubilio Bp.). Verh Int Ver Limnol 16: 1176-1181.

Cloutman DG. 1903. Monogenean and copepod parasites of fishes from the Smoky Hill River, Ellis County, Kansas. Trans Kans Acad Sci 77: 225-230.

Dalu T, Nhiwatiwa T, Clegg B, Barson M. 2012. Impact of Lernaea cyprinacea Linnaeus 1758 (Crustacea: Copepoda) almost a decade after an initial parasitic outbreak in fish of Malilangwe Reservoir, Zimbabwe. Knowl Manag Aquat Ecosyst 406: 03. DOI:10.1051/ kmae/2012020.

Demaree RS. 1967. Ecology and external morphology of Lernea cyprinacea. Am Mid Nat 78: 416-427.

Djikanovic V, Paunovic M, Nikolic V, Simonovic P, Cakic P. 2012. Parasitofauna of freshwater fishes in the Serbian openwaters: a checklist of parasites of freshwater fishes in Serbia open waters. Rev Fish Biol Fish 22: 297-324.

Fast MD. 2014. Fish immune response to parasitic copepod (namely sea lice) infection. Dev Comp Immunol 43: 300-312. DOI: 10.1016/j.dci.2013.08.019.

Fratello B, Sabatini MA. 1972. Cariologia e sistematica di Lernaea cyprinacea L. (Crustacea, Copepoda). Atti Accad Naz Lincei Rend Sci Fis Mat Nat 53: 209-213.

Freyhof J. 1998. First record of Pomatoschistus canestrinii (Ninni, 1883) in Lake Trasimeno. Riv Idrobiol 37: 107-108.

Giardino C, Bresciani M, Villa P, Martinelli A. 2010. Application of remote sensing in water resource management: the case study of Lake Trasimeno, Italy. Water Res Manag 24: 3885-3899. DOI:10-107/s11269-010-9639-3.

Giovinazzo G, Antegiovanni P, Dörr AJM, Elia AC. 2006. Presence of Bothriocephalus acheilognathi (Cestoda: Pseudophyllidea) in Atherina boyeri del Lago Trasimeno. Ittipatologia 3: 61-67. (In Italian with English summary).

Hossain MMM, Rahman MZ, Islam MA, Alam ME, Rahman H. 2013. Lernaea (anchor worm) investigations in fish. Int J Agric Food Sec 1: 12-19.

Innal D, Avenant-Oldewage A, Dogangil B, Stavrescu-Bedivan MM, Ozmen O, Mavruk S. 2017. Susceptibility of endemic and nonindigenous fish to Lernaea cyprinacea (Copepoda: Lernaeidae): a case study from Düger Spring Creek (Burdur, Turkey). Bull Eur Assoc Fish Pathol 37: 96-105.

Intergovernmental Panel on Climate Change (IPCC). 2007. Contribution of working group II to the fourth assessment report of the intergovernmental panel on climate change, 2007. In: Parry ML, Canziani OF, Palutikof PJ, van der Linden PJ, Hanson CE, eds. Chapter 12. Europe. Cambridge (UK): Cambridge University Press.

Iqbal Z, Shafqat A, Haroon F. 2012. Lernaea diversity and infection in Indian and Chinese Carps under semi-intensive culture conditions in Lahore, Punjab. J Anim Plant Sci 22: 923-926.

Kabata Z. 1979. Parasitic Copepoda of British Fishes. London: Royal Society.

Kadlec D, Šimková A, Jarkovsky J, Gelnar M. 2003. Parasite communities of freshwater fish under flood conditions. Parasitol Res 89: 271-283.

Koyun M, Ulupinar M, Mart A. 2015. First record of Lernaea cyprinacea L 1758 (Copepoda: Cyclopoidea) on Cyprinion macrostomus Heckel, 1843 from eastern Anatolia, Turkey. Biharean Biol 9: 44-46.

Krasnovyd V, Kvach Y, Drobiniak O. 2012. The parasite fauna of the gobiid fish (Actinopterygii, Gobiidae) in the Sukhyi Lyman, Black Sea. Vestn Zool 46: 483-490. (In Russian with English summary).

Kritscher E. 1975. Die Fische des Neusiedlersees und ihre Parasiten. II. Parasitische Copepoden und Branchiuren. Ann Naturhist Mus Wien 79: 589-596.

Kupferberg SJ, Catenazzi A, Lunde K, Lind AJ, Palen WJ. 2009. Parasitic copepod (Lernaea cyprinacea) outbreaks in foothill yellow-legged frogs (Rana boylii) linked to unusual warm summers and amphibian malformations in Northern California. Copeia 2009: 529-537.

Kvach Y. 2002. The round goby's parasites in native habitats and in a place of invasion. Oceanol Stud 31: 51-57.

Kvach Y. 2004. The metazoan parasites of gobiids in the Dniestr estuary (Black Sea) depending on water salinity. Oceanol Hydrobiol Stud 33: 47-56. 
Kvach Y, Korniychuk Y, Mierzejewska K, Rubtsova N, Yurakhno V, Grabowska J, Ovcharenko M. 2014. Parasitization of invasive gobiids in the eastern part of the Central trans-European corridor of invasion of Ponto-Caspian hydrobionts. Parasitol Res 113: 1605-1624. DOI:10.1007/s0043-014-3791-2.

Kvach Y, Boldyrev V, Lohner R, Stepien CA. 2015. The parasite community of gobiid fishes (Actinopterygii: Gobiidae) from the lower Volga River region. Biologia 70: 948-957. DOI: 10.1515/ biologia-2015-0108.

Lorenzoni M, Giovinazzo G, Mearelli M, Natali M. 1993. Growth and biology of perch (Perca fluviatilis L.) in Lake Trasimeno (Umbria, Italy). Pol Arch Hydrobiol 40: 313-328.

Lorenzoni M, Corboli M, Dörr AJM, Giovinazzo G, Selvi S, Mearelli M. 2002. Diets of Micropetrus salmoides Lac. and Esox lucius L. in Lake Trasimeno (Umbria, Italy) and their diet overlap. Bull Fr Pêche Piscic 365/366: 537-547.

Lorenzoni M, Ghetti L, Pedicillo G, Carosi A. 2010. Analysis of the biological features of the goldfish Carassius auratus auratus (Linnaeus, 1758) in Lake Trasimeno (Umbria, Italy) with a view to drawing up plans for population control. Folia Zool 58: 56-70.

Ludovisi A, Gaino E. 2010. Meteorological and water quality changes in Lake Trasimeno (Umbria, Italy) during the last fifty years. J Limnol 69: 174-188. DOI:10.3274/JL10-69-1-16.

Ludovisi A, Gaino E, Bellezza M, Casadei S. 2013. Impact of climate change in the hydrology of shallow Lake Trasimeno (Umbria, Italy): History, forecasting and management. Aquat Ecosyst Health Manag 16: 190-197. DOI: 10.1080/14634988.2013.789776.

Macchioni F, Chelucci L, Torracca B, Prati MC, Magi M. 2015. Fishes and their parasites in the water district of Massaciuccoli (Tuscany, Central Italy). Vet Ital 51: 199-203. DOI:10.12834/ Vetlt.230.733.1.

Marcogliese DJ. 2001. Implications of climate change for parasitism of animals in the aquatic environment. Can J Zool 79: 1331-1352.

Marcogliese DJ. 2008. The impact of climate change on the parasites and infectious diseases of aquatic animals. Sci Tech Rev Int Off Epizoot 27: 467-484.

Marcogliese DJ, Locke SA, Gélinas M, Gendron AD. 2016 Variation in parasite communities in spottail shiners (Notropis hudsonius) linked with precipitation. J Parasitol 102: 27-36.

Marina H, Beatty SJ, Morgan DL, Lymbery AJ. 2008. An introduced parasite, Lernaea cyprinacea L., found on native freshwater fishes in the south west of Western Australia. JR Soc West Aust 91: 149-153.

McAllister CR, Bursey CR, Martin SD. 2011. Lernaea cyprinacea (Crustacea: Copeoda: Lernaeidae). Anchorworms from two larval qautic insects (Ephemeroptera: Batidae, Trichoptera: Hydropsycidae) in northeastern Oklahoma. Proc Okla Acad Sci 91: 37-40.

Medeiros ESF, Maltchik L. 1999. The effect of hydrological disturbance on the intensity of infestation of Lernaea cyprinacea in an intermittent stream fish community. $J$ Arid Environ 43: 351-356.

Miller PJ. 2004. The freshwater fishes of Europe. Vol. 8/II. Gobiidae 2. Wiebelsheim: Aula Verlag, $477 \mathrm{p}$.

Nagasawa K, Inoue A, Myat S, Umino T. 2007. New host records of Lernaea cyprinacea (Copepoda), a parasite of freshwater fishes, with a checklist of the Lernaeidae in Japan (1915-2007). J Grad Sch Biosp Sci Hiroshima Univ 46: 21-33.

Narum SR, Campbell NR, Meyer KA, Miller MR, Hardy RW. 2013. Thermal adaptation and acclimation of ectotherms from differing aquatic climates. Mol Ecol 22: 3090-3097. DOI:10.1111/mec.12240.
Piasecki W, Goodwin AE, Eiras JC, Nowak BF. 2004. Importance of copepod in freshwater aquaculture. Zool Stud. 43: 193-205.

Pompei L, Franchi E, Giannetto D, Lorenzoni M. 2012. Growth and reproductive properties of tench, Tinca tinca Linnaeus, 1758 in Trasimeno Lake (Umbria, Italy). Knowl Manag Aquat Ecosyst 406: 07. DOI:10.1051/kmae/2012024.

Pónyi J, Molnár K. 1969. Studies on the parasitic fauna of fish in Hungary V. Parasitic copepods. Parasit Hung 2: 137-148.

Raibaut A, Combes C, Benoit F. 1998. Analysis of the parasitic copepod species richness among Mediterranean fish. J Mar Syst 15: 185-206.

Raissy M, Sohrabi HR, Rashedi M, Ansari M. 2013. Investigation of a parasitic outbreak of Lernaea cyprinacea Linnaeus (Crustacea: Copepoda) in cyprinid fish from Choghakhor lagoon. Iran J Fishs Sci 12: $680-688$

Salinas ZA, Biolé FG, Grenat PR, Pollo FE, Salas NE, Martino AL. 2016. First report of Lernaea cyprinacea (Copepoda: Lernaeidae) in tadpoles and newly-metamorphosed frogs in wild populations of Lithobates catesbeianus (Anura: Ranidae) in Argentina. Phyllomedusa 15: 43-50.

Sánchez-Hernández J. 2017. Lernaea cyprinacea (Crustacea: Copepoda) in the Iberian Peninsula: climate implications on hostparasite interactions. Know Manag Aquat Ecosyst 414: 11. DOI: $10.1051 / \mathrm{kmae} / 2017002$.

Shariff M, Roberts RJ. 1989. The experimental histopathology of Lernaea polymorpha $\mathrm{Yu}$ 1938. Infection in naive Aristichthys nobilis (Richardson) and a comparison in naturally infected resistant fish. J Fish Diseases 12: 405-414.

Shields RJ, Tidd WM. 1968. Effect of temperature on the development of larval and transformed females of Lernaea cyprinacea L. (Lernaeidae). Crustaceana 15 (Suppl 1), Studies on Copepoda: 87-95.

Stavrescu-Bedivan MM, Popa OP, Popa LO. 2014. Infestation of Lernaea cyprinacea (Copepoda: Lernaeidae) in two invasive fish species in Romania, Lepomis gibbosus and Pseudorasbora parva. Know Manag Aquat Ecosyss 414: 12. DOI:10.1051/kmae/2014024.

Stavrescu-Bedivan MM, Popa PO, Aioanei FT, Popa LO. 2011. Infestation of the pumpkinseed Lepomis gobbosus (Teleostei: Cyprinidae) by the copepode Lernaea cyprinacea (Crustacea) some ecological aspects. Trav Mus Nat d'Hist Nat "Grigore Antipa" 54: 63-68. DOI: 10.2478/v10191-011-0004-4

Tidd WM. 1934 Recent infestation of goldfish and carp by the "anchor parasite", Lernaea carassii. Trans Am Fish Soc 64: 176-180.

Waicheim MA, Blasetti G, Cordero P, Rauque CA, Viozzi GP. 2017. The invasive copepod Lernaea cyprinacea Linnaeus, 1758 (Copepoda, Cyclopoidea, Lernaeidae): first record for Neuquén River, Patagonia, Argentina. Check List 13: 997-1001. DOI:10.15560/13.6.997.

Walter TC, Boxshall G. 2018. World of Copepods database, http:// www.marinespecies.org/copepoda (on 2018-03-18).

Webb BW, Nobilis F. 2007. Long-term changes in river temperature and the influence of climatic and hydrological factors. J Hydrol Sci 52: 74-85.

Whitaker JO, Schlueter RA. 1975. Occurrence of the crustacean parasite, Lernaea cyprinacea, on fishes from the White River at Petersburg, Indiana. Am Midl Nat 93: 446-450.

Zhokhov AE, Pugachev MN, Molodozhinkova NM. 2017. Parasites of the invasive goby Proterorhinus semilunaris (Pisces: Gobiidae) in Rybinsk reservoir and checklist of the parasites of gobiids (genus Proterorhinus) in Eurasia. Russ J Biol Inv 8: 18-33.

Cite this article as: Ahnelt H, Konecny R, Gabriel A, Bauer A, Pompei L, Lorenzoni M, Sattmann H. 2018. First report of the parasitic copepod Lernaea cyprinacea (Copepoda: Lernaeidae) on gobioid fishes (Teleostei: Gobonellidae) in southern Europe. Knowl. Manag. Aquat. Ecosyst., 419, 34 